\title{
Die pluriformiteitsleer van Abraham Kuyper
}

Teologiese onderbou vir die konsep van aparte kerke vir aparte volksgroepe?

WD Jonker, Stellenbosch

\begin{abstract}
Abraham Kuyper's doctrine of the pluriformity of the church In their defence of the idea of separate churches for different population groups, some South African theologians made use of Abraham Kuyper's concept of the pluriformity of the church. The author investigates the reasons why and the way in which Kuyper used this concept. He argues that Kuyper used it in defence of the right of orthodox Christians to leave liberal churches and to form their own churches, without the fear of effecting a sinful secession. However, the result is that Kuyper, making use of patterns of thought borrowed from the spirit of the nineteenth century, departed from the traditional Reformed view on the unity of the church. Although the author is convinced that Kuyper's motives differed from those of the South African theologians, he has no doubt that they could rightfully claim that they were following his authoritative lead.
\end{abstract}

Abraham Kuyper het deur sy ekklesiologie in Suid-Afrika baie invloed uitgeoefen, veral op die teologie van die Nederduitse Gereformeerde Kerk. Onder andere het hy deur sy visie op die kerk en deur sy pluriformiteitsleer ' $n$ instrument aan Suid-Afrikaanse teoloë voorsien waarmee hulle sedert die veertiger jare die konsep van aparte kerke vir aparte volksgroepe teologies probeer onderhou het. Maar het dit werklik ten regte geskied?

Om hierdie vraag te kan beantwoord, is dit belangrik om te probeer verstaan wat Kuyper presies bedoel het. Hy het uiteraard in ' $n$ totaal ander situasie gedink en geskryf as dié wat tans in Suid-Afrika bestaan. Sy teologie moet verstaan word teen die agtergrond van die spesifieke kerklike stryd waarin hy betrokke was en die teologiese klimaat waarin hy geadem het.

\section{DIE VOLKSKERK}

Daar is verskillende motiewe wat ' $n$ rol gespeel het in die totstandkoming van Kuyper se leer van die pluriformiteit van die kerk (of ook: pluriformiteit van kerke, soos hy hom by geleentheid uitdruk (Kuyper. 1909:618). Hierdie motiewe hang egter ten nouste saam met die én groot motief : Kuyper se patos vir die behoud van die gereformeerde belydenis en religie, waardeur hy skerp krities gestaan het teenoor die situasie van die historiese volkskerk waaraan hy verbonde was.

12 - In die Skriflig 1989, 23 (3) 
Kuyper het haas nie genoeg woorde om sy misnoee oor en selfs afkeer van die Nederlandse Hervormde Kerk as massakerk tot uitdrukking te bring nie. Die volkskerk omvat 'n goot menigte van mense wat om tradisionele redes tot die kerk behoort, sonder dat hulle geestelik in die ware lewe van die kerk deel. Dit herberg in homself 'n veelheid van denkrigtings en oortuigings wat almal gelyke regte en aansprake het, en is nie by magte om deur leertug die suiwerheid van belydenis te handhaaf nie. Dit verteenwoordig dus ' $n$ onnatuurlike en valse eenheid en vorm 'n dwangbuis waarbinne elemente wat geestelik nie bymekaar hoort nie, tog in een organisasie saamgebind word. Kerk en wëreld word op hierdie wyse vermeng, en die ware eenheid van die kerk, die eenheid in Christus wat alleen aanwesig kan wees tussen diegene wat een van gees en belydenis is, word daardeur verhinder (vergelyk sy rede: Vrijheid, in: Kuyper 1913: 395-411).

Histories hang dit volgens Kuyper daarmee saam dat kerk en staat sedert Konstantyn verbonde geraak het en in 'n nabootsing van die situasie van die Ou Testament, daarvan uitgegaan het dat alle landsburgers sover moontlik binne die een staatskerk verenig moet wees. Die Reformasie het hierin nie werklik met die Roomse gedagte gebreek nie, en so het die verskillende volkskerke ontstaan, hoewel dit nie Gods bedoeling was dat die kerk 'n "Griekse of Egiptiese of Romeinse kerk" moes geword het nie, maar wêreldkerk moes bly wat haar selfstandigheid teenoor die volkere moes bewaar het (Kuyper, 1893:121-123). "De volkskerk is de poging om het Joods-Christelijke voort te zetten" (aangehaal uit De Heraut 1887, no 477 deur Langman, 1950: 88).

Daarom ken Kuyper maar een groot begeerte, en dit is om van die volkskerk en sy valse, uiterlike en ongeestelike eenheid weg te kom, sodat die ware geestelike eenheid van egte gelowiges ervaar kan word in 'n kerk waarin die suiwer gereformeerde belydenis die band sal wees wat hulle saambind. Omdat hy dit onmoontlik ag om die massakerk te kan reformeer sodat dit weer 'n suiwer kerk van Christus kan wees, wil hy dit liewer prysgee. Hy het egter prinsipiele besware daarteen dat sonder meer van die bestaande kerk afgeskei en 'n nuwe kerk gestig moet word. Dit mag alleen gedoen word as ' $n$ mens die volkskerk tot valse kerk kan verklaar waarvan daar om Christus ontwil uitgegaan moet word. Kuyper het egter nie die vrymoedigheid gehad om van die Nederlandse Hervormde Kerk, selfs in sy toestand van verwording en deformasie, te verklaar dat dit ' $n$ valse kerk is nie.

Daarom sien hy slegs eén oplossing: die volkskerk moet opgelos word in 'n aantal vrye kerke wat gevorm word deur diegene wat van dieselfde oortuiging en gevoel is. In sy studie Tractaat van de reformatie der kerken (1884) werk hy die strategie uitvoerig uit wat daarby gevolg moet word, sodat daar nie sprake is van die stigting van 'n nuwe kerk nie, maar van die reformasie van die bestaande. Daarby het hy veral op die oog dat kerkrade tot reformasie moet oorgaan deur hulle van die bestaande organisasie van die volkskerk los te maak en tot die instelling van 'n nuwe kerkverband te kom, wat vir sy besef iets anders is as af. skeiding van die bestaande kerk (Kuyper, 1884:134 e.v.). 
Maar hoe dan ook, Kuyper is van mening dat uit die een massa-kerk deur opsplitsing verskillende kerkgroeperinge moet ontstaan in ooreenstemming met die beginsels wat deur die onderskeie groepe binne die kerk bepleit word. Dit kan sonder kwade gevoelens teenoor mekaar geskied, want nie een van die vrye kerke wat so tot stand kom, sal homself as die enigste ware kerk beskou, en die andere as valse kerke brandmerk nie. Uiteraard sal elkeen se eie kerk volgens sy eie oortuiging die suiwerste openbaring van die kerk van Christus wees, maar daarmee word nie geimpliseer dat die ander kerke nie ook ware kerke kan wees nie, al is hulle dan minder suiwer of selfs gedeformeer.

\section{DIE EENHEID VAN DIE KERK}

Die vraag wat hiermee direk na vore kom, is hoe Kuyper dan oor die eenheid van die kerk gedink het. Klaarblyklik bedoel die opsplitsing van die volkskerk in 'n aantal vrye kerke vir hom geensins dat die eenheid van die kerk daardeur in gedrang kom nie. Vir Kuyper is die eenheid van die kerk immers in die eerste plek iets onsigbaars. As ons bely dat ons glo aan die eén, heilige, algemene Christelike kerk, betoog Kuyper, is dit ' $n$ geloofswaarheid. Dit gaan daarby om die unio essentialis van die kerk, en bedoel nie "om uit te drukken, dat er niet meerdere kerken zijn of zijn kunnen, maar om aan te duiden, dat de leden der kerk eéne onverbrekelijke eenheid uitmaken, saam én organisch geheel zijn en dat dit éne lichaam altoos en overal hetzelfde hchaam is" (Kuyper, s.a. IV, 80).

Die belydenis van die eenheid van die kerk dui net soos die belydenis van die heiligheid en katolisiteit van die kerk 'n attribuut van die kerk aan. Die attribute van die kerk is kenmerke van die onsigbare kerk, nie van die sigbare kerk nie. Die notae van die kerk (suiwere prediking, bediening van die sakramente, kerklike tug) is van toepassing op die sigbare kerk. Die attribute raak die inwendige wese van die kerk en geld van die kerk as organiese grootheid, as die liggaam van Christus, maar is nie op die kerk as instituut van toepassing nie. Dit word selfs deur die kerk as instituut weerspreek, want die kerk was nie net alleen op aarde nog nooit sigbaar een nie en sal dit ook nooit wees nie, maar hoef dit ook nie te wees nie. Die kerk besit sy eenheid in Christus as iets onverliesbaars. Waarvoor Christus in Johannes 17 gebid het, was dan ook nie vir die eenheid van die kerk nie, maar vir die eenheid van die lede van die kerk, wat op so 'n sondige manier hulle geestelike eenheid kan misken en so teenoor mekaar verdeeld kan wees (Kuyper, s.a.: IV, 81). Hulle geestelike eenheid hoef egter nie sigbare uitdrukking binne een kerklike instituut te vind nie.

Die teenstelling wat Kuyper tussen die kerk as organisme en die kerk as instituut konstrueer, is hier van groot gewig. Onder die kerk as instituut verstaan Kuyper iets uiterliks wat nie tot die wese van die kerk behoort nie en niks anders is nie as ' $n$ "instituut voor den dienst des Woords" (Kuyper, 1893:134). Dit val nie met die kerk saam nie, want die kerk is die organiese grootheid wat bestaan uit die individuele gelowiges. Die instituut is deur die kerk vir die kerk ingestel as 'n noodsaaklike instrument om die diens van die Woord in stand te hou, niks meer nie.

\section{4 - In die Skriflig 1989, 23 (3)}


Die kerk het wel die instutêre vorm nodig om 'n geformeerde kerk te wees, maar dit is kerkisme om die sigbare instituut as behorende tot die wese van die kerk te beskou (Kuyper, 1893:146). Die wesenlike eenheid van die kerk kom dus volgens Kuyper nie in gedrang deur die bestaan van 'n groot aantal kerklike institute naas mekaar nie.

Die sigbare eenheid is volgens hom selfs nie iets wat op die aardse bestaan van die kerk van toepassing is nie. Dit sal eers eskatologies gerealiseer word. In sy toespraak oor De eenvormigheid, de vloek van het moderne leven (1869) gaan Kuyper uitvoerig hierop in. Hy gaan daarvan uit dat die eenheid die einddoel van al Gods weê is, maar dat dit eers gerealiseer sal word as God uit die bonte veelheid en verskeidenheid van die skepping en die geskiedenis alle stryd sal verwyder in die komende koninkryk van die hemel. Dit is die lis van die sonde en die boosheid om die mens te verlei om reeds hier op aarde die ideaal van eenheid te wil bereik. Die eenheidstrewe van die moderne lewe is selfs 'n vloek, want dit beoog ' $n$ valse eenheid wat die verskeidenheid dooddruk en alles nivelleer. Terwyl God bedoel dat daar in sy skepping 'n harmonie tussen al die verskeidenhede moet bestaan, wil die valse eenheidstrewe juis alle verskeidenheid wegskaaf en die vryheid vernietig.

Toegepas op die kerk, redeneer Kuyper dan dat die Reformasie die valse eenheid en eenvormigheid van Rome deurbreek het deurdat die nasionale gees en die individuele vryheid na bowe gekom het. Daardeur kon die vryheid van gewete en die ontluiking van die verskeidenheid weer 'n kans kry. Ongelukkig het die Reformasie hierin egter halfpad bly vassteek. Weliswaar het dit die eenheid van die sigbare wêreldkerk verbreek, maar dit het die eenvormigheid slegs getemper, deurdat dit self ook weer onder druk van die nasionalisme volkskerke tot stand gebring het wat op hulle beurt die eenvormigheid weer ingevoer het, en daardeur opnuut die reg van die individu as vrye persoonlikheid gesmoor het (Kuyper, 1869:27).

Hierdie eenvormigheid moet volgens Kuyper "niet slechts door het nationaal verzet als in de dagen der Hervorming gelocaliseerd, maar door de volle kracht van het persoonlijk geestesleven geheel gebroken worden", deurdat "men zonder de minste nevengedachte, vrij en onverholen, de vrije veelvormigheid" moet aanvaar. Dus: Wie kerkherstel wil bewerk, moet daarvan uitgaan dat alle eendersdenkendes binne die massakerk hulleself vrywillig saamsluit: "Laat zo met volkomen autonomie zich groepen en kringen verenigen, die weten wat ze willen. weten wat ze belijden, en voor wie de eenheid in het leven bestaat en niet in eenheid van naam" (Kuyper, 1869:31).

So sal dan volgens Kuyper 'n aantal vrye plaaslike kerke ontstaan wat hulleself konfederatief kan saamsluit in verskillende nuwe kerkverbande. Eers so sal die ware eenheid weer terugkeer. Want die veelheid van kerke het met die verskeurdheid van die kerk as sodanig nog niks te make nie, al kan daar ook verskeurdheid kom as daar op 'n sondige manier uitmekaar gegaan en teenoor mekaar opgetree word (Kuyper. $1904: 231)$. Sulke vyandigheid is wel sonde, maar nie die veelheid van kerke as sodanig nie. Dit openbaar immers juis die ryke verskeidenheid 
van standpunte en oortuigings, geestesgesteldheid en kulture wat binne die een kerk van Christus voorkom. En dit hoort vir Kuyper by die pluriformiteit van die kerk.

\section{DIE REFORMASIE, DIE BELYDENIS EN DIE SKRIF}

Kuyper maak dus geen geheim daarvan dat hy op hierdie punt met die Reformasie verskil nie. Hy is egter van mening dat die Reformasie hierin ongelyk gehad het. Volgens hom was die Reformatore nog nie bewus van die geweldige oorgang wat die Reformasie met sy klem op die vryheid van die gewete beteken het nie. Hulle het nog geen oog gehad vir die pluriformiteit van die kerk nie en het hulle eie kerk gesien as die wettige voortsetting van die kerk van die apostels. Bowendien was hulle van oortuiging dat hulle belydenis ' $n$ absolute en eksklusiewe karakter gedra het, en dat die waarheid wat absoluut is, ook in die eenheid van vorm en inhoud uitdrukking moes vind (Kuyper, 1904 : 263-268). Alle Reformatore het aanvanklik op die standpunt gestaan van die sigbare eenheid van die kerk, net soos die drie Formuliere van Eenheid ook vanuit hierdie gesigspunt opgestel is. Hierdie oortuiging het gesteun op die gewoonte, maar ook op al die uitsprake van die Nuwe Testament waarin so ontroerend oor die eenheid van die kerk gepraat word (Kuyper. 1904:229-231).

Maar later, onder die drang van die werklikheid van die lewe en die realiteit van die verdeeldheid van die kerk, het daar 'n breuk met hierdie sienswyse ingetree. Die Protestantse kerke kon nie hulle eenheid behou nie, ondanks alle pogings om dit te bewaar. Verskillende konfessionele kerke het in dieselfde land naas mekaar tot stand gekom, en hoewel daar deur 'n bepaalde modus vivendi tussen hulle nog die skyn van eenheid opgehou is, het die pluriformiteit van die kerk daarmee tog 'n werklikheid geword. So het daar 'n wysiging van oortuiging ingetree. "En hierdoor nu is het gekomen, dat in onze Formulieren van Enigheid, en zo ook bij onze oude dogmatische schrijvers, het denkbeeld van de eenheid der zichtbare kerk nog stand hield, terwijl toch in het werkelijke leven steeds openhartiger met de pluriformiteit der zichtbare kerk gerekend werd" (Kuyper, 1904:230).

Maar leer die Skrif dan nie die eenheid van die kerk nie? Hierdie vraag is geregverdig, omdat Kuyper in sy verdediging van die pluriformiteit hom deurgaans op die geskiedenis beroep, waarin die werklikheid van die verdeeldheid van die kerk sonder meer 'n gegewe is. Wanneer hy op hierdie vraag ingaan, word die swakheid van sy posisie duidelik. Dit blyk dan al gou dat hy nie vanuit die Skrif tot sy standpunt oor die pluriformiteit gekom het nie, maar dat dit inpas by 'n totale dogmaties-wysgerige konstruksie. Daarom neem hy sy toevlug nie tot eksegese nie, maar tot 'n redenasie op grond van die idee van evolusie.

Sy eerste opmerking is dat "elke plant die zich later in vele stengels splitst, toch in de aanvang eén is, en dat er op dien grond niets onnatuurlijks in ligt, dat ook de kerk in haar eerste opkomen nog niet in haar onderscheidene stengels zou uiteengaan" (Kuyper, 1914:231). Kuyper se liefde vir biologiese en organiese beelde tree hier na vore. Die kerk is

$$
16 \text { - In die Skriflig 1989, } 23 \text { (3) }
$$


in die begin nog in sy embrionale stadium, en daaruit kan nie afgelei word dat alles altyd so moes bly nie. Die kerk se bestaan is onderworpe aan dieselfe lewenswette wat vir die ganse skepping geld. Groei en ontwikkeling bring noodwendig splitsing en veelvormigheid mee. "Pluriformiteit is naar onze vaste overtuiging een phase van ontwikkeling waartoe ook de kerk in het zichtbare moest komen" (Kuyper, 1904:231). Soos alle ander lewensvorme moes ook die kerk ontplooi vanaf die aanvanklike eenheid tot die latere veelvormigheid. Op hierdie wyse kom die ganse rykdom van die veelvuldige wysheid van God tot openbaring (Kuyper, 1904:234).

Die Bybelse uitsprake oor die eenheid van die kerk is dus vir Kuyper nie genoegsame rede om die idee van die veelheid van kerke as onbybels te sien nie. Hy vind selfs allerlei redes om sy idee van die pluriformiteit as in ooreenstemming daarmee te kan sien. Paulus het immers sy briewe altyd net aan een gemeente of aan een landstreek gerig, redeneer hy, en die apostels het geen maatreels getref om die eenheid van die kerk vir die toekoms te waarborg nie. "Ze hebben blijkbaar de eenheid in het geestelijke, niet in de eéne uitwendige organisatie gezocht" (Kuyper, 1904:232).

Bowendien - en daarmee kom Kuyper tereg waar hy eintlik wil wees - is daar in die Nuwe Testament ook reeds die eerste spore van die pluriformiteit, omdat Pualus sy evangelie telkens in ander terme vertolk het vir gemeentes onder verskillende omstandighede. Met die Romeine praat hy in regsterme, maar met die Efesiers in terme wat aansluit by wysgerige opvattings wat vir hulle aktueel was. En sê Paulus dan nie in 1 Korintiers 9 dat hy vir almal alles geword het nie? "Een hoogst opmerkelijke uitspraak, waarin het denkbeeld der pluriformiteit gefundeerd ligt." Daarom kan Kuyper tot die slotsom kom: "Geven we dus volmondig toe, dat er van kerk naast kerk in het Nieuwe Testament nog geen spoor te ontdekken valt, alsmede dat de eenheid 'an Christus' kerk dogmatisch gedurig op de voorgrond treedt, uit niets blijkt dat eenvormige organisatie van alle kerken voor all eeuwen bedoeld is. Veeleer zijn de sporen duidelijk aanwezig, die tonen, dat de uiting van het leven der kerk verschillen moet naar gelang van den kring waarin ze optreedt" (Kuyper, 1904:232).

\section{DIE SUBJEKTIEWE FAKTOR}

By hierdie punt wou Kuyper uitkom, want hier lê die werklike fondament vir sy leer van die pluriformiteit. Dit is die feit dat die menslike lewe as sodanig 'n ryke verskeidenheid vertoon, en dat die kerk in sy sigbare verskyningsvorm nie anders kan as om daarby aan die sluit nie. In ooreenstemming met sy onderskeiding tussen instituut en organisme redeneer Kuyper dat nie die instituut nie, maar die gelowiges self volgens die Nuwe Testament die kerk uitmaak (Kuyper. 1898:53-56). Dit gaan om die mense wat gelowig word. En omdat daar verskeidenheid onder die mense bestaan, "moest het verschil dat mens en mens scheidt, ook als wigge in de eenheid der uitwendige kerk dringen" (Kuyper. 1898:55). "De mensen zijn niet eender onder wie de kerk optreedt. Ze verschillen naar herkomst. ras, land. streek, verleden, aanleg, gemoedsstemming en 
zielsbestaan, en ook blijven ze niet altoos dezelfde, maar doorlopen verschillende trappen van ontwikkeling" (Kuyper, 1904:233).

In hierdie verband lê Kuyper groot klem op wat hy die subjektiewe faktor in die verstaan en vertolking van die evangelie noem. Volgens hom het die Reformasie deur sy klem op die vryheid van die gewete "nu eenmaal aan het subjectieve element" regmatige betekenis verleen, en dit moes noodwendig op pluriformiteit uitloop. "Zeker, de waarheid is een, en het Woord één, en één de verlichting van de Heilige Geest, maar als het er nu aan toekomt, om in het subjectief bewustzijn de waarheid op te nemen, en ze in een eigen menselijk woord uit te spreken, dan breekt de ene lichtstraal in haar veelheid van tinten, en bloeit het uitgestrooide zaad op, niet in een bed van eén enkele bloemsoort, maar in een rijke variatie van bloemgewas, wier eenheid in de harmonie, en niet langer in de gelijksoortigheid noch in de gelijkvormigheid ligt" (Kuyper. 1904:240).

Hier word dit baie duidelik dat dit eintlik die verskil in die subjektiewe visie op die waarheid is, wat vir Kuyper die grond van sy pluriformiteitsleer is. Dit beteken egter dat die waarheidsgehalte van die belydenis gerelativeer word. Dit verteenwoordig maar een gesigspunt onder baie wat ewe goed reg van bestaan het. Ongetwyfeld het Kuyper bedoel dat die verskille maar net in die vormgewing bestaan, terwyl die waarheid basies vir almal dieselfde is. Maar dit is juis problematies. Die werklikheid van die verskeurdheid van die kerk weens dwaling en leuen dreig om heeltemal uit die gesigsveld te verdwyn vanwee die sterk klem wat op die regmatige verskeidenheid geplaas word. Die teenstelling tussen ware en valse kerk maak plek vir die verskil tussen suiwer en minder suiwer kerke. Soos sy kritici (Bensdorp, Gunning, Kromsigt, Schilder, Berkouwer en andere) tereg opgemerk het, word die sonde van die verdeeldheid in die kerk onskadelik gemaak deur die voorstelling van die skone harmonie van die veelheid van gesigspunte.

Die beginsel wat hieragter skuil, sou egter later een van die grondpilare van sy Encyclopaedie vorm, en hang daarmee saam dat Kuyper juis die erkenning van die subjektiewe faktor as kenmerkend vir die moderne tyd beskou het en doelbewus daarby wou aansluit. Wanneer hy dit as sy doel stel om "het eigen confessioneel bewustzijn op te heffen tot de hoogte van de bewustzijnsvorm onzer eeuw" (Kuyper, 1909:635), dan het dit spesifiek ook hiermee te make. Die subjektiewe, antropologiese faktor moet in die geloof en teologie ten volle in berekening gebring word. Sodra dit egter gebeur, tree in wat Kuyper "de ontluiking der pluriformiteit" noem (Kuyper, 1919:614). Want dan word dit duidelik dat verskille in landsaard en sedes, neiging en gemoedslewe, diepte en oppervlakkigheid daartoe moes lei "om hier de eéne, daar de andere zijde van het eéne zelfde beeld der waarheid meer eenzijdig in het oog te doen vatten. Vandaar de vele denominatien of gezindheden waarin het kerkelijk leven, krachtens dit beginsel, is uiteengegaan" (Kuyper. 1898:55; vergelyk Kuyper, 1911:321).

So ag Kuyper dit met name ook ondenkbaar dat mense van 'n geheel ander ras as ons "in onze confessie en in onze catechismus de passende 
uitdrukking van hun geloof zullen vinden" (Kuyper. 1904:233). Die verskil in ras en kultuur is vir Kuyper in die eerste plek belangrik vir sover dit verklaar waarom daar verskil in die persepsie van die waarheid bestaan. Sy pleidooi vir 'n veelheid van kerke kom dus nie voort uit die gedagte dat volk, ras en kultuur verskillende kerke noodsaaklik maak, omdat 'n kerk 'n "volkse kerk" moet wees nie. Daarteen stry hy juis in sy verwerping van die volkskerk en hy verklaar ook uitdruklik dat 'n nasionale kerk wat slegs een volk omvat, 'n heidense of hoogstens 'n Joodse gedagte is (Kuyper, 1898:56). Dit gaan vir Kuyper om die oortuiging dat verskil in begrip van die waarheid op belydenisverskille uitloop, en dat dit tot vrye ekspressie moet kom. Maar binne hierdie konteks speel die verskeidenheid van volk, ras en kultuur tog 'n rol in die formasie van die kerk wat ten volle aanvaar moet word (Kuyper, 1911:191-202).

Op die feit van die subjektiwiteit van die waarheid baseer Kuyper die pluriformiteit van die kerk, op die feit dat mense nie eenders is nie en dat die kerk om werklik in hulle lewe te kan indring, homself moet aanpas by die lewe. Pluriformiteit is vir hom 'n veelheid van kerke: 'n kerk vir elke ras, vir elke land, vir elke sosiale geleding, vir elke konfessionele groepering, vir elke groep wat uit innerlike aandrang hulle eie kerk wil stig. Dit het vir hom deurgaans te make met wat ons vandag die "kontekstualiteit" van die waarheid sou noem. Maar hy trek daaruit die konklusie dat elke skakering in die insig in die waarheid tot die stigting van 'n afsonderlike kerk mag lei, sonder dat dit beteken dat die eenheid van die kerk van Christus daardeur verbreek word.

\section{KUYPER EN DIE NEGENTIENDE EEU}

Daarmee is die hooftrekke van Kuyper se leer van die pluriformiteit van die kerk geskets. Dit is duidelik dat dit vir Kuyper gedien het as 'n teologiese wapen in sy stryd teen die Nederlandse volkskerk en vir die verwesenliking van sy ideaal om 'n vrye, belydende gestalte van die kerk na vore te laat tree. Maar daarmee is tog nie alles gesê nie. Dit feit waarop ons hierbo gewys het, naamlik sy aansluiting by die aksent op die subjektiewe of antropologiese element in teologie en belydenis, dui daarop dat Kuyper welbewus nie maar net die reformatoriese posisies van die sestiende eeu wou repristineer nie, maar in aansluiting by die subjektiwistiese tendens van die negentiende eeu die gereformeerde posisies nuut wou deurdink.

Daarvan is ook sy leer van die pluriformiteit van die kerk 'n voorbeeld. Nie die Skrif nie, maar die geskiedenis en die sosiale werklikheid is die grond vir Kuyper se leer van die pluriformiteit van die kerk. Die werklikheid van die lewe self, en met name die werklikheid van die diversiteit wat aanwesig is in die subjektiewe toeëiening van die waarheid, bring hom daartoe om ' $n$ visie op die sigbare bestaanswyse van die kerk in die wêreld te ontwikkel waarvoor hy geen Skrifgronde hoegenaamd het nie, maar wat inpas by 'n bepaalde dogmaties-wysgerige visie op die werklikheid as 'n organiese geheel wat evolusioner ontwikkel en in dié proses die ganse rykdom ontplooi wat God aan die begin in sy skepping gelê het. Veenhof merk in hierdie verband op: "Op deze wijze construeerde Kuyper in feite een openbaring Gods buiten Christus en de

In die Skriflig 1989, $23(3)-19$ 
Schrift om en importeerde zo een brok natuurlijke theologie in zijn leer omtrent de kerk" (Veenhof, 1969:124).

Dit is nie toevallig dat Kuyper in sy uiteensetting van die pluriformiteit telkens gebruik maak van biologiese en organiese beelde nie. Die organisme-begrip het in die teologie van die negentiende eeu 'n groot rol gespeel. Dit het Van Leeuwen nie moeilik geval om op hierdie punt allerlei verbindingslyne tussen Kuyper en die Romantiek, maar ook tussen hom en teoloe soos Vinet, Rothe, Schleiermacher en andere te trek nie (Van Leeuwen, 1946:117, 264). Kuyper kon die organisme-begrip maklik assimileer deur dit by die gereformeerde verbondsleer aan te hak, en daardeur het dit in sy denke 'n groot en beslissende invloed verkry. Die gevaar by hom is dat hy vanuit die organisme-begrip allerlei elemente oorneem en dit in sy ekklesiologie hanteer asof dit geopenbaarde waarheid is. Sy hele idee dat dit ' $n$ wet van Gods skepping is dat alles as 'n eenheid begin, maar dan deur ' $n$ proses van ontwikkeling heen in verskeidenheid moet ontplooi om eers eenmaal aan die einde wear in 'n volmaakte eenheid sigbaar te word, is natuurlik nie aan die Skrif ontleen nie, maar word aan die Skrif opgelê. Tog speel dit 'n groot rol in sy pluriformiteitsleer

Dit is egter nie net die organisme-idee wat ons aan Kuyper se historiese verbondenheid met die negentiende eeu herinner nie; dit is ook die sterk klem wat hy op die vryheid lê. Vir hom is vryheid van gewete cen van die vernaamste vrugte van die Reformasie. Maar daaruit trek hy ook swaarwigtige konklusies vir die bestaanswye van die kerk, kor.klusies wat alleen moontlik is teen die agtergrond van die negentiende eeuse individualisme. Herhaaldelik beklemtoon hy dat die kerk bestaan uit wedergebore persone, en dit is hierdie individue wat die sigbare gestalte van die kerk volgens hulle vrye keuse kan konstitueer (Kuyper, 1884:27).

'n Mens moet maar sy uiteensetting in sy rede oor Eenvormigheid of die strekking van Het Calvinisme rustig beskou, om te sien hoe sterk die persoonlikheidsideaal en die ideaal van die individuele vryheid by Kuyper deurgewerk het. Dit is op grond van hierdie vryheid dat Kuyper die reg opeis dat almal wat eendersdenkend is, hulle eie kerk mag stig. Vir die kerk as moeder van die gelowiges, soos Calvyn daaroor gepraat het, het Kuyper nie veel gevoel nie. Na sy sigbare gestalte is die kerk die resultaat van die vrywillige besluit van 'n aantal individue, weliswaar op aandrang van die Gees in die individuele harte, om hulle eie kerk te stig. Daarom kan hy ook sẽ: "Monarchiaal is Christus' Koningschap, maar de regering der kerk op aarde (is) democratisch in merg en been" (Kuyper, 1898:54). Dat Kuyper en die Doleantie in hulle kerkreg na die independentisme oorgeleun het, is bekend en hoef hier nie verder bespreek te word nie.

Nee, daaroor kan daar geen twyfel wees nie: Kuyper was 'n magtige figuur, 'n uiters begaafde mens en teoloog, maar hy was ook 'n kind van sy tyd, en hoewel hy Bavinck se rede oor die katolisiteit van Christendom en kerk hoog geprys het, is dit tog duidelik dat hy die katolisiteit anders as Bavinck heeltemal tot die onsigbare kerk beperk het, en bereid was om mee te gaan met die gees van die negentiende eeu - wat die eeu 
was van die vermenigvuldiging van kerke en kerkies. Dat hy krities gestaan het teenoor die gedagte van afskeiding van die kerk, werp hierby nie soveel teengewig in die skaal nie, want sy visie op die kerk bring uiteindelik mee dat hy die opsplitsing van die sigbare kerk alleen maar kan toejuig as die openbaring van die veelkleurige rykdom van die wysheid van God. 'n Mens kry selfs die indruk dat dit volgens Kuyper geld: Hoe meer kerke, hoe meer vreugde (Theron, 1989:87).

\section{EENHEID EN VERSKEIDENHEID}

Ons sien dus by Kuyper die merkwaardige ding gebeur dat hy begin by 'n pleidooi vir die openbaring van ware eenheid van die kerk in teenstelling tot eenvormigheid, maar dat hy vanwee 'n bepaalde onvermoe om eenheid en verskeidenheid saam te dink, in werkhkheid tot 'n pleidooi vir uniforme afsonderlike kerke kom. Die verskeidenheid waaroor hy so hoog opgee, is 'n verskeidenheid wat sover moontlik buite die kerk as gemeenskap van eendersdenkendes gehou moet word. Hy wil die eenheid sowel as die verskeidenheid vashou, maar hy sien eenheid en verskeidenheid as 'n teenstelling, sodat hulle mekaar wedersyds uitsluit.

Net so stel ook die kategorieë sigbaar en ongsigbaar teenoor mekaar. Hy kan nie reg daaraan laat geskied dat wat onsigbaar waar is, ook in die sigbare na vore moet tree nie, al is dit dan ook gebrekkig. Hy probeer nèrens om dudielik te maak waarom verskeidenheid en eenheid wel op 'n onsigbare wyse en kragtens skepping en voleinding verbonde kan wees, maar nie in die sigbare kerk ook verenig kan word nie. Hy poneer eenvoudig op grond van die geskiedenis dat dit nie gebeur het nie en redeneer op grond van die sosiologiese werklikheid dat verskeidenheid vanself op 'n veelheid van sigbare kerkformasies moet uitloop.

Oor die feit dat hy die sosiologiese werklikheid raakgesien het, kan daar nie met hom getwis word nie. Die merkwaardige van Kuyper is dat hy reeds in sy tyd soveel insig gehad het in die verskynsel van die kontekstualiteit. Kuyper het volkome gelyk gehad dat die kerk werklik inheems moet word in die lewe van die volkere en kulturele groeperinge binne die mensheid en dat daarmee ten volle rekening gehou moet word in die bestaan van die kerk. In hierdie sin is sy stryd teen eenvormigheid ook volkome ter sake. Die problematiese van sy posisie is egter dat hy daaruit die konklusie trek dat kontekstualisering noodwendig tot ' $n$ veelheid van kerke moet lei. As enigste alternatief daarvoor sien hy slegs 'n oppervlakkige en gedwonge eenheid en eenvormigheid waaruit die geestelike dimensie weg is.

Maar is die Bybelse weg nie dat gelowiges te midde van alle verskeidenheid en kontekstualiteit mekaar juis nie moet loslaat nie. maar mekaar moet vashou vanuit hulle geestelike eenheid, en só mekaar tot diens moet wees nie? Verskeie kritici van Kuyper het daarop gewys dat die pluriformiteit binne die een kerk gehandhaaf moet word, om juis so reg te laat geskied aan die rykdom van Gods waarheid. Binne die een kerk van Christus kart gelowiges mekaar help om ook ander fasette van die waarheid raak te sien as dié wat binne hulle konteks na die enigste lyk. Om Christus ontwil mag hulle mekaar nie eenvoudig loslaat, terwyl 
elkeen sy eie insig verabsoluteer nie, maar hulle moet mekaar oor en weer korrigeer en aanvul, sodat hulle "saam met alle gelowiges" (Ef $3: 18$ ) die volheid van die waarheid beter kan begryp (Berkouwer, 1970:75) . Daar moet binne die een kerk van Christus ruimte wees vir 'n pluraliteit van insig en spiritualiteit, sonder dat die band met mekaar daardeur verbreek hoef te word. Dit is wel die moeiliker weg, maar dit is waarskynlik tog die "suiwerder" weg.

\section{TEN REGTE?}

Ten slotte 'n enkele woord oor die vraag of die beroep op Kuyper se pluriformiteitsidee deur Suid-Afrikaanse teoloe tot regverdiging van die idee van aparte kerke vir aparte volkere werklik ten regte was. Dit het nie net in die verlede 'n groot rol in die debat oor kerklike eenheid binne die Nederduitse Gereformeerde Familie van kerke gespeel nie (Kinghorn. 1986:121; Ridderbos. 1975:67; Lategan, 1975:316-318), maar speel nog steeds 'n rol daarin. Dit sou maklik wees om die invloed daarvan op die dokument Ras, volk en nasie in die lig van die Skrif (1974) aan te dui, asook die spore daarvan in die latere Kerk en Samelewing (1986). In 'n groot mate is dit ook die basis van die publikasie Geloof en Protes waarin die standpunte van die beswaardes teen die uitsprake van Kerk en Samelewing verwoord word.

Daaroor kan ons slegs sè: Kuyper se motief was nie dieselfde as dié van die Suid-Afrikaanse teoloe wat hulle op hom beroep nie. Sy blikpunt was die eenheid, suiwerheid en kontekstualiteit van die belydenis, terwyl hulle blikpunt die volkse karakter van die kerk is. Daarin is hulle sterk deur politieke motiewe beinvloed, iets wat by Kuyper ontbreek. Selfs al bestry hulle saam met Kuyper die idee van 'n volkskerk in die sin van 'n massakerk, is die band tussen kerk en volk vir hulle so wesenlik, dat hulle vir aparte kerke vir aparte volksgroepe pleit, ook waar daar eenheid van belydenis bestaan. Dit is moeilik om te sê of Kuyper hiervoor vaderskap sou wou aanvaar.

Maar terselfdertyd sal daar gesê moet word dat hulle hulself tog nie sonder reg op hom beroep nie. Hulle beroep hulle daarop dat Kuyper die volkereverskeidenheid onder die faktore noem wat die formasie van die kerk bepaal. Inderdaad hanteer Kuyper in sy verdediging van die pluriformiteit argumente wat aan skepping en voorsienigheid ontleen is om te bewys dat verskille in taal, kultuur, ras en volk noodwendig tot verskille in belydenis moet lei, en dat sulke belydenisverskille op hul beurt afsonderlike kerkformasies noodsaaklik maak. Omdat die sigbare kerk vir Kuyper deur die individuele gelowiges vrywillig gekonstitueer word, is dit logies dat hulle daarop geregtig is om 'n kerk te vorm wat by hulle pas. Via die subjektiewe faktor in die toeeiening van die waarheid lei etniese veelvormigheid dus vanself daartoe dat 'n veelheid van kerke op etniese grondslag sal ontstaan (Heyns, 1984:79).

Op die swakheid van sy redenasies in hierdie verband het ons reeds gewys. Ook van Kuyper geld dit dat ons maar ten dele ken en ten dele profeteer. Daar sit iets tragies in dat juis hy wat na die waarheid van die Skrif terug wou roep, die duidelike boodskap van die Skrif oor die eenheid van die kerk op hierdie wyse kragteloos gemaak het. So het hy 
daaraan meegewerk dat daar met 'n goeie gewete gepleit kon word vir die stigting van aparte kerke op rasse-grondslag. Die onwil om die gemeenskap van die heiliges met Christene van dieselfde belydenis (en soms ook nog met dieselfde taal) oor die kleurgrens heen te beoefen, word in feite op sy gesag goedgepraat.

Al was sy motief anders as dié van sommige van diegene wat hulle daarvoor op hom beroep, leen sy pluriformiteitsleer homself daartoe om so gebruik te kan word. Sy gedagtes het in die Suid-Afrikaanse teologie daartoe gedien om 'n tendens te sanksioneer wat reeds in die sendingaksies van die negentiende eeu bestaan het en in aansluiting by die Duitse Sendingwetenskap verdedig is. Sy invloed was daarin onberekenbaar groot.

\section{LITERATUUR}

Berkouwer, GC. 1970. De kerk I. Kampen: Kok.

Coenen, L. 1952. Gemeinde und Synode. Eine kritische Untersuchung ihrer Beziehungen in den reformierten Kirchen der Niederlande. Doktorale proefskrif, Universiteit van Gottingen. Ongepubliseer.

Die Voortsettingskomitee 1987. Geloof en Protes. 'n Antwoord namens beswaarde lidmate op sekere aspekte van "Kerk en Samelewing". Pretoria: Aurora Pers.

Heyns. HS. 1984. Die invloed van Abraham Kuyper se kerkbegrip op die ekklesiologiese denke binne die NG Kerk. Lisensiaatskripsie, Universiteit Stellenbosch. Ongepubliseer.

Algemene Sinode van die Nederduitse Gereformeerde Kerk. 1986. Kerk en Samelewing. 'n Getuienis van die Ned Geref Kerk. Bloemfontein: NG Sendingpers.

Kinghorn. J. 1986. Die NG Kerk en apartheid. Johannesburg: MacMillan.

Kuyper, A. 1869. Eenvormigheid, de vloek van het moderne leven. Amsterdam: De Hoogh.

1884. Tractaat van de Reformatie der Kerken. Amsterdam: Hoveker en Zoon. 1893. E Voto Dordraceno II. Amsterdam: Wormser.

1898. Het Calvinisme. Tweede druk. Kampen: Kok.

1904. De gemeene gratie III. Amsterdam/Pretoria: Hoveker en Wormser.

1909. Ėncyclopaedie der heiligen Godgeleerdheid II, 2de druk. Kampen: Kok

1911. Pro Rege II. Kampen: Kok.

1913. Predicatien. 3de druk. Kampen: Kok.

s.a. Dictaten Dogmatiek IV. 2de druk. Kampen: Kok

Langman. HJ. 1950. Kuyper en de volkskerk. Kampen: Kok

Lategan. BC. 1975. "Met die oog op wat nuttig is . ." NGTT. XVI: 314-322.

Ridderbos, HN. 1975. Pluralisme en eenheid. Geref Weekblad, XXXI: 67. 17 Oktober

Swart. GJ. 1959. Die vraagstuk van die eenheid, verskeidenheid en verdeeldheid van die kerk. Doktorale proefskrif. Universiteit van Pretoria. Pretoria: V en R Drukkery.

Theron. PF. 1989. Corpus Christi, katolisiteit en Kuyper. (In PF Theron en J Kinghorn. Koninkryk. kerk en kosmos. Bloemfontein: Pro Christo p 87-100.)

Van leeuwen. PA. 1946 Het kerkbegrip in de theologie van Abraham Kuyper Francker: Wever

Veenhof, C. 1969 Volk van God Enkele aspecten van Bavincks kerkbeschouwing Amsterdam: Buiten en Schipperheijn. 